\title{
PENDIDIKAN SEKS PADA ANAK USIA DINI DIPANDANG DARI AGAMA ISLAM
}

\author{
Fadila Abdullah
}

\section{PENDAHULUAN}

Salah satu masalah orang tua yang sudah bekerja adalah menentukan pola asuh bayi, balita, atau anak usia dini dengan perasaan aman dan nyaman. Karena kesalahan pola asuh anak usia dini, orang tua menjadi menyesal seumur hidup. Sekarang ini, orang tua berkeinginan untuk sukses mengasuh anak, tetapi juga sukses berkarir. Untuk menentukan pola asuh anak usia dini, orang tua harus mampu mengukur kemampuan diri. Setiap orang tua pasti ingin mengasuh anak-anaknya dengan baik. Ketika bekerja, anak harus dengan siapa apakah bersama pembantu, kakek, nenek, tetangga, dititipkan ditempat penitipan anak atau griya asuh bayi dan balita. Semua itu memiliki konsekuensi dengan segala resikonya. Dalam realitas seperti ini, orang tua harus mampu mengukur kemampuan diri, tenaga, pikiran, dan kemampuan ekonomi. Hanya saja, orang tua merupakan pola asuh anak, tidak berfikir pentingnya keamanan, kenyamanan, pengaruh sosial, dan lingkungan anak. Kerena orang tua lengah dan tidak waspada, anak banyak yang dijahili, bahkan sampai terjadi tindak kekerasan seksual. Mereka yang ada disekeliling kita yang selama ini dianggap baik, menyayangi, dan melindungi ternyata melukai, jika sudah demikian, orang tua hanya bisa menyesal seumur hidup.

Keluarga merupakan pembentuk tingkah laku, tingkat moral dan pendidikan kepada anak. Selama ini, pendidikan seks untuk anak usia dini dianggap tabu dikalangan masyarakat. Orang tua beranggapan bahwa pendidikan seks belum pantas diberikan pada anak kecil. Padahal dengan pendidikan seks diberikan sejak dini sangat berpengaruh dalam kehidupan anak ketika mereka memasuki masa remaja. Apalagi anak - anak sekarang mereka lebih kritis, dari segi pertanyaan dan tingkah laku karena pad masa ini anakanak memiliki rasa keingintahuan yang besar. Pendidikan seks dalam keluarga merupakan salah satu alternatif dalam membekali anak-anak dengan informasi informasi tentang seks, kesehatan, dan masalah reproduksi secara benar. Kemampuan, ketrampilan dan kemauan orang tua dalam memberikan seks akan menentukan perasaan anak pada masa yang akan datang.

Anak usia 3-5 Tahun sudah mampu menyadari perbedaan gender saat berinteraksi dilingkungannya. Sehingga sejak anak berusia 3 tahun harus mendapat pendidikan seks dari orang tua mereka. Anak-anak yang kurang diperhatikan oleh orang tua mereka akan lebih mudah terbujuk oleh perilaku mesra lawan jenis mereka. Kasus kekerasan terhadap anak di Indonesia terus memprihatinkan, setelah terungkapnya sejumlah kasus diberbagai tempat, termasuk kasus pedofilia dengan jumlah korban mencapai ratusan anak.

Menurut arist Merdeka sirait, ketua Komisi Nasional Perlindungan Anak (Komnas PA), jumlah kasus kekerasan seksual pada anak meningkat dari tahun ke tahun. Jika pada tahun 2012 jumlahnya 124 kasus, maka di " tahun ini mencapai 200 kasus dengan jumlah korban hampir 300 anak". Seto Mulyadi, psikolog anak mengatakan, anak-anak korban kekerasan seksual harus mendapat perhatian serius baik dari keluarga maupun dari pemerintah, tidak hanya memulihkan kondisi traumatik tetapi juga agar mereka tidak berubah menjadi pelaku di kemudian hari.

Informasi Pendidikan Seks Dalam Keluarga

Saat ini, kekurangan informasi yang benar tentang masalah seks akan memperkuatkan 
kemungkinan seorang anak percaya salah paham yang diambil dari media massa dan teman sebaya. Akibatnya, akan beresiko melakukan perilaku berbahaya untuk kesehatannya. Ternyata keluarga merupakan salah satu yang mampu bertindak memberikan pendidikan seks kepada anak di Indonesia yang sangat efektif. Fakta-fakta ini memperkuat kebutuhan untuk menerima pendidikan seks yang diberikan orang tuanya secara tepat merupakan informasi tentang seks sebagai pendidikan didalam keluarga.

Kapan pendidikan seks tepat untuk ditanamkan, tidak ada batasan yang pasti. Orang tua bisa mengajarkan pendidikan seks untuk anaknya tepat pada saat anak mulai mengajukan pertanyaan. Jawaban yang harus diberikan tentunya mengacu pada usia anak. Semakin dewasa usianya dapat memberitahukan dengan informasi yang lebih lengkap menurut Alya Andika dalam bukunya berbicara Seks Bersama Anak.

Maraknya kasus pelecehan seksual akhirakhir ini seperti pemerkosaan, sodomi serta beragam kasus lainnya, memunculkan ide pendidikan seksual dini pada anak, beragam panduan pendidikan seks anak berusia dini pun muncul diantaranya adalah mengajarkan pada anak untuk mengenali bagian-bagian tubuh sensitivenya, menjaga diri agar si anak tidak membiarkan orang asing menyentuh bagian-bagian sensitivenya serta mengajarkan agar berteriak jikalau ada yang mencoba menyentuh bagian tubuh sensitivenya. Apakah ini saja cukup tentang pendidikan seksual dini pada anak?. Jika tujuannya hanya untuk melindungi dari kasus-kasus pelecehan seksual tentu hal ini sudah sangat lebih dari cukup bagi anak. Namun pertanyaannya, apakah tujuan pendidikan seksual hanya untuk melindungi anak dari kasus pelecehan seksual?, berdasarkan hemat kami yang berkecimpung di dunia anak dan remaja jawabannya tentu tidak.
Sementara kalau kita lihat di dunia khususnya barat (yang masih dijadikan acuan) dalam pendidikan seksual pada anak ternyata tujuan pendidikan seks pada anak tidak hanya untuk menjaga diri dari pelecehan seksual, itu hanya salah satu dari sekian banyak tujuannya. Ada beberapa tujuan pendidikan seks menurut konsep barat diantaranya "Menekankan pentingnya kesetiaan terhadap pasangan, menghindari kehamilan di usia dini, menghindari pelecehan seksual, mampu menghindari hubungan seks yang tidak diinginkan atau seks tidak aman, keuntungan menunda seks", kalau kita lihat poin-poin pendidikan seks dibarat acuannya lebih kepada mengamankan diri si anak dari pelecehan seksual serta menjaga agar tidak terkena penyakit menular. Artinya dibolehkan melakukan hubungan seksual selagi itu aman, selama itu suka sama suka (tidak ada paksaan) yang alhasil output dari pendidikan ini adalah seks bebas.

Lalu bagaimana dengan pendidikan seks usia dini untuk anak dalam Islam?, dalam islampun sangat memperhatikan hal ini namun perlu diketahui output dari pendidikan seks dalam Islam adalah terjaganya seorang anak dunia akhirat, terjaga di dunia dari pelecehan serta berbagai penyakit seks menular dan kedua adalah terjaga keselamatan dunia akhiratnya dengan menyalurkan naluri seksual secara halal (melalui pernikahan), lalu bagaimana pendidikan seks dalam islam kepada anak?, berikut akan kita coba urai satu persatu tentang pendidikan seks usia dini pada anak.

\section{Menanamkan kebiasaan menutup aurat pada anak sejak dini.}

"Tidak ada asap kalau tidak ada api" , mungkin kita semua sudah sangat familiar dengan istilah ini yang maknanya adalah segala sesuatu ada sebab akibatnya termasuk juga berbagai kasus pelecehan seks yang terjadi pada anak-anak. Tentu tidak akan mungkin atau kecil kemungkinan terjadinya jika tidak ada hal 
yang memancing seseorang untuk melakukan pelecehan seksual salah satunya adalah cara berpakaian anak-anak perempuan, mungkin ini adalah yang terlupakan oleh berbagai penggerak pendidikan seks usia dini yaitu membiasaakan si anak menutup aurat sejak dini. Karena kalau kita lihat kebanyakan para orang tua membiarkan atau malah dengan sengaja memakaikan anak-anak perempuannya pakaian yang terbuka, serba pendek, minim dan transparan. Bahkan tak sedikit yang membiarkan anak perempuannya bermain di jalan (luar rumah) hanya dengan memakai celana dan baju dalam, mungkin dalih mereka anak kecil belum berdosa jika belum menutup auratnya.

Memang anak kecil sebelum masa baligh (datangnya haid pertama) belum berdosa jika auratnya terbuka, namun anak-anak usia dini tersebut adalah saat yang tepat membentuk kebiasaannya menutup aurat, saat yang tepat mengenalkan padanya mana saja bagian tubuhnya yang termasuk aurat dan tidak boleh dilihat oleh orang lain (bukan mahromnya). In syaa Allah ini termasuk pada bagian penting dan utama dalam pendidikan seks anak usia dini, karena dengan menjaga diri atau menutup aurat sejak kecil si anak sudah berusaha untuk tidak menjadi "api" atau meminimalisir penyebab terjadinya pelecehan seksual terhadap dirinya.

\section{Mengenalkan pada anak mana yang Mahram dan mana yang bukan mahram}

Lagi-lagi dengan dalih masih kecil para orang tua terkadang tidak terlalu menghiraukan anaknya bersentuhan dengan siapa saja, apakah itu dengan temannya, orang lain dan dengan orangorang yang bukan mahramnya, pada poin kedua ini para orang tua mengajarkan pada anak siapa saja yang mahramnya (orangorang yang boleh menyentuh dia serta melihat auratnya), dengan mengajarkan hal ini, tentu akan membangun kebiasaan untuk selalu menjaga diri pada si anak, tidak dengan mudah bersentuhan dan disentuh oleh siapapun. Salah satu contoh kasus yang menarik adalah kebiasaan yang diajarkan di salah satu Sekolah dasar islam terpadu cahyati di kota bukittinngi yang mana disana terlihat anak-anak perempuan sejak usia kelas 1 SD sudah tidak bersalaman secara bersentuhan dengan guru laki-lakinya. Artinya anak-anak disana memahami kalau guru laki-laki tersebut bukan mahramnya.

Pemahaman ini tentu akan sangat berguna bagi si anak untuk menjaga dirinya dari berbagai pelecehan seksual dan juga untuk menjaga dirinya hingga dewasa dari berbagai aktivitas-aktivitas seperti pacaran, pergaulan atau kumpul bebas dengan lakilaki dan perempuan serta aktivitas-aktivitas yang memungkinkan terjadinya seks bebas.

\section{Memisahkan tempat tidur anak laki- laki dengan anak perempuan}

"Suruhlah anak-anakmu shalat ketika mereka berumur tujuh tahun, dan pukullah mereka (tanpa menyakitkan jika tidak mau shalat) ketika mereka berumur sepuluh tahun; dan pisahkanlah tempat tidur mereka." (HR. Abu Dawud)

Memisahkan tempat tidur anak laki-laki dan perempuan ketika sudah berumur 7 tahun, dimana pada usia ini anak sudah mengenali perbedaan jenis kelamin, maka salah satu cara terbaik yang juga mengajarkan pada anak kalau laki-laki perempuan itu terpisah adalah memisahkan tempat tidur anak laki-laki dan perempuan.

\section{Menjauhi anak dari tontonan dan musik-musik yang bermuatan "seks", "cinta" dan "pacaran"}

Salah satu keputusan besar dalam keluarga kami untuk tidak memiliki televisi adalah karena sejauh pengamatan kami hampir semua materi tontonan di televisi apakah itu sinetron, musik, film atau apapun itu hampir semuanya bermuatan cinta, pacaran dan seks. Meskipun tidak terang-terangan 
namun semua hal yang berbau cinta yang akhirnya disalurkan dalam aktivitas pacaran yang mana dalam setiap aktivitas pacaran tentu tidak lengkap jika tidak ada aktivitas pegangan, gandengan tangan, ciuman serta adegan-adegan lainnya. Hal ini secara tidak lansung mengajarkan tentang "seks" karena yang namanya cinta pada lawannya tentu tidak bisa dipisahkan dengan naluri seks, Ibnul qayyim al jauzi menyebut ini sebagai "al hawa" cinta yang memiliki muatan syahwat.

Begitu juga dengan berbagai nyanyian musik dan lagu yang notabene tematemanya adalah cinta dan pacaran semua, bahkan kita semua tentu tau ada musik dengan penyanyi anak-anak berusia sekolah dasar yang menyanyikan lagu bertema cinta dan pacaran. Tak dipungkiri hal ini menyebabkan terjadinya pacaran di usia dini, pelecehan seksual usia dini, anak-anak kecil yang sudah memiliki pemikiran terlalu dewasa melebihi usianya dan berbagai hal-hal negatif lainnya.

\section{Mengajarkan anak untuk dekat pada masjid, dekat dengan Al-quran serta mempelajari sejarah-sejarah Islam di masa lalu.}

Selain aktivitas-aktivitas diatas yang bisa dimasukkan sebagai bagian dari pendidikan seks usia dini pada anak adalah mengajarkan anak-anak kita dekat dengan masjid (jika laki-laki) biasakan shalat berjamaah dimasjid, setelah itu mengajarkan alquran pada anak sejak kecil (bahkan bisa dilakukan sejak dia berada dalam rahim) tentu dengan melakukan hal ini berarti menanamkan nilai-nilai ilahi pada dirinya sejak dini akan memudahkan kita memberikan pemahaman-pemahaman Islam padanya.
Dan yang terakhir, sering terlupakan adalah menceritakan sejarah Islam, tokohtokoh islam pada anak sejak dini agar anak tidak kehilangan teladan (idola) tidak salah pilih idola atau teladan. Sangat disayangkan jika anak-anak kita malah menjadikan idolanya kartun-kartun buatan barat, artis-artis hollywood yang jauh dari nilai-nilai Islam.

Ya, itulah 5 hal yang bisa dijadikan sebagai bahan pendidikan seks pada anak kita sejak usia dini, begitulah mengajarkan tentang seks pada anak dalam Islam, lebih berfokus pada pembangunan karakter dan kepribadian Islamnya. Karena jika karakter dan kepribadian Islam sudah terbangun tentu akan memudahkan si anak untuk memahami hal-hal lain termasuk pergaulan dalam Islam.

\section{DAFTAR PUSTAKA :}

1. Achmadi, Islam sebagai Paradigma Ilmu Pengetahuan, Semarang: Aditya Media, Salemba. 2013

2. Arifin, Hubungan Timbal Balik Hubungan Agama Pendidikan Agama di Lingkungan Sekolah dan Keluarga, Jakarta : Bulan Bintang. 2012

3. Wisnu Supriatna, Pendidikan Seks Anak dalam Keluarga menurut Abdullah Nashih Wulwan. Skripsi UIN Jakarta 2011.

4. Kasus Pelecehan Seksual Terhadap Anak Makin mengkhawatirkan. http.//Ucannews.com/2014/5/08

5. Ariwibowo, mendidik Seks Pada anak , http.//lifestyle bisnis.com/2015 